This is the post-print version of Bergek, A., Berggren, C., Magnusson,, T., Hobday, M., 2013. Technological discontinuities and the challenge for incumbent firms: Destruction, disruption or creative accumulation? Research Policy, 42 (6-7), 1210-1224 (http://dx.doi.org/10.1016/j.respol.2013.02.009). Please refer to the published version and also note that this version might differ slightly from the published version.

\title{
Technological discontinuities and the challenge for incumbent firms: destruction, disruption or creative accumulation?
}

\author{
Anna Bergek ${ }^{\mathrm{a}, *}$, Christian Berggren ${ }^{\mathrm{a}}$, Thomas Magnusson ${ }^{\mathrm{a}}$ and Michael Hobday ${ }^{\mathrm{a}, \mathrm{b}}$ \\ ${ }^{a}$ KITE Research Group, Department of Management and Engineering, Linköping University, \\ SE-581 83 Linköping, Sweden. \\ ${ }^{b}$ CENTRIM (Centre for Research in Innovation Management), the Freeman Centre, \\ University of Brighton Falmer, Brighton, East Sussex BN1 9QE, England.
}

\begin{abstract}
The creative destruction of existing industries as a consequence of discontinuous technological change is a central theme in the literature on industrial innovation and technological development. Established competence-based and market-based explanations of this phenomenon argue that incumbents are seriously challenged only by 'competence-destroying' or 'disruptive' innovations, which make their existing knowledge base or business models obsolete and leave them vulnerable to attacks from new entrants. This paper challenges these arguments. With detailed empirical analyses of the automotive and gas turbine industries, we demonstrate that these explanations overestimate the ability of new entrants to destroy and disrupt established industries and underestimate the capacity of incumbents to perceive the potential of new technologies and integrate them with existing capabilities. Moreover, we show how intense competition in the wake of technological discontinuities, driven entirely by incumbents, may instead result in late industry shakeouts. We develop and extend the notion of 'creative accumulation' as a way of conceptualizing the innovating capacity of the incumbents that appear to master such turbulence. Specifically, we argue that creative accumulation requires firms to handle a triple challenge of simultaneously (a) fine-tuning and evolving existing technologies at a rapid pace, (b) acquiring and developing new technologies and resources and (c) integrating novel and existing knowledge into superior products and solutions.
\end{abstract}

Key words: creative accumulation, technological discontinuity, creative destruction, disruptive innovation, competence-destroying innovation

\section{Introduction}

The effect of discontinuous technological change on existing industries is a central theme in the literature on industrial innovation and technological development. Technological discontinuities can lead to intensified technological competition or even to a complete breakdown of competitive patterns (Abernathy and Clark, 1985; Anderson and Tushman, 1990; Utterback and Suarèz, 1993). As a consequence, a process of "creative destruction" (Schumpeter, 1942/1994) may unfold, which eventually leads to the demise of established firms. Extant literature suggests two main explanations for this observed difficulty of incumbent firms to respond to discontinuous technological change. The first explanation

*Corresponding author. Postal address: Department of Management and Engineering, Linköping University, SE58183 Linköping, Sweden. Tel. +46-13-282573. Fax: +46-13-281101. E-mail addresses: anna.bergek@liu.se (A Bergek), christian.berggren@liu.se (C. Berggren), thomas.magnusson@liu.se (T. Magnusson) and michaelghobday@gmail.com (M. Hobday). 
argues that incumbents fail when "competence-destroying” discontinuous innovations render their existing knowledge base obsolete (Tushman and Anderson, 1986), and the second explanation focuses on customer and market dynamics, arguing that incumbents are seriously challenged only when innovations introduce new performance attributes that incumbents perceive as unimportant (e.g. Christensen, 1997/2003; Christensen and Rosenbloom, 1995; Rosenbloom and Christensen, 1994).

While these two explanations present different perspectives on the failure of leading firms, they share the common assumption that industry incumbents are burdened with "core rigidities” and the legacy of old technology (Leonard-Barton, 1992). Therefore, technological discontinuities may open up possibilities for new entrants. This is a key assumption in several modern versions of Schumpeterian creative destruction - from the competence-based studies in Tushman and Anderson (1986) and Utterback and Suarez (1993) to the more recent market-based approach of disruptive innovation (Christensen, 2006). A complementary assumption is that the absence of successful new entrants signifies periods of stability, in which industry incumbents will retain and strengthen their competitive positions.

This paper challenges these assumptions. With detailed longitudinal analyses of two sets of comparative cases - electric vehicles and hybrid powertrains in the auto industry, micro turbines and combined cycle gas turbines in the power generation sector - we identify overoptimism regarding new entrants' abilities to disrupt established industries, partially generated by the above theories. We show how intense competition in the wake of technological discontinuities, driven entirely by incumbents, may result in dramatic shakeouts in mature industries, but also how some incumbents are capable of absorbing the new technologies and integrate them with their existing capabilities. We develop the notion of "creative accumulation” as a way of conceptualizing the innovating capacity of these successful incumbents, a concept originally coined by Pavitt (1986) to describe the process of generating new knowledge, which builds on existing knowledge rather than replacing it. Based on our case analyses, we elaborate this concept and emphasize its dual nature, including accumulation as well as creativity: whereas the accumulation aspect creates barriers to entry and offsets the attacker's advantage, the creativity aspect poses severe challenges also for incumbent firms, particularly in industries where products are composed of a multitude of technologies and represent a variety of performance attributes. This analysis has important managerial implications. A general suggestion for firms which need to deal with exploitative and explorative activities simultaneously is to implement ambidextrous organisations, which 
separate various types of search and innovation (Raisch and Birkinshaw, 2008). Our analysis indicates that in a competition characterized by creative accumulation, firms need sustained efforts of dynamic integration rather than separation.

The paper is organized as follows. The next section outlines competence-based and marketbased explanations of the difficulties of incumbent firms to respond to discontinuous technological change. Section 3 presents our research design, including the rationale for case selection and methods for data collection, and section 4 describes discontinuous technological change and its consequences in the two studied industries. Thereafter, section 5 analyses the reasons why attackers failed and incumbents struggled in the selected cases. It also elaborates on the concept of creative accumulation as a means to explaining this. Section 6, Conclusions, summarises the analysis and the main findings of the paper, and is followed by a final section, Discussion, which outlines the organizational implications of creative accumulation.

\section{Explaining the effects of discontinuous technological change on incumbents' competitive positions}

\subsection{Schumpeterian innovation and 'creative destruction'}

With the concept of creative destruction, Schumpeter (1942/1994, p. 84) was among the first to draw attention from price competition to competition "which commands a decisive cost or quality advantage and which strikes not at the margins of the profits and the outputs of the existing firms but at their foundations and their very lives.” Much of the later work in this tradition has emphasized the “attacker’s advantage” (Foster, 1986) over incumbents: “the 'creation' is usually accomplished by invaders - new firms or entrants from other industries while the 'destruction' is suffered by the incumbents” (Rosenbloom and Christensen, 1994, p. 656). The more general issue of interest highlighted by Schumpeter is, however, the implications of discontinuous innovation for the success or failure of innovating firms in their rivalry with both actual and potential competitors (cf. Abernathy and Clark, 1985).

Several theoretical frameworks have been developed to explain under what circumstances discontinuous technological change is likely to result in the demise of incumbent firms. On a general level, innovation scholars have argued that discontinuous innovation exposes leading firms to situations where the existing values, norms and structures upon which they traditionally have built a competitive edge, turn into rigidities that limit their ability to innovate (Leonard-Barton, 1992). Concepts such as competence-destroying innovation 
(Tushman and Anderson, 1986), architectural innovation (Henderson and Clark, 1990) and disruptive innovation (Christensen and Rosenbloom, 1995) have been used to describe the main competitive challenge for incumbents. The first two of these concepts are competencebased explanations of incumbent failure, and can be contrasted with the third concept, disruptive innovation, which can be seen as a market-based explanation (cf. also Macher and Richman, 2004).

\subsection{Competence-based explanations of creative destruction}

According to competence-based explanations, the competitive outcomes of a discontinuous innovation depends on its influence on firms' existing resources, skills and knowledge: some innovations destroy existing technological competences and capabilities, whereas other refine and improve them (Abernathy and Clark, 1985). Tushman and Anderson (1986) label these types “competence-enhancing” and “competence-destroying”, respectively.

Competence-enhancing discontinuities are order-of magnitude improvements in price/performance that build on existing knowledge and skills (Tushman and Anderson, 1986). They refine and extend an established product design, usually by improving individual components (Henderson and Clark, 1990). Competence-enhancing discontinuities are generally introduced by incumbent firms (Gilbert, 2012), and also tend to reinforce the competitive positions of these firms, since they permit incumbents to exploit their existing competences and increase barriers to entry (Abernathy and Clark, 1985; Henderson and Clark, 1990; Tushman and Anderson, 1986). Few, if any, new firms enter an industry as the result of a competence-enhancing discontinuous innovation (Maine and Garnsey, 2006). This explains the observation that old and large firms seem to have better chance of survival throughout industry evolution (Klepper, 1996) as well as observations from many sectors of stable patterns of innovation, in which incumbents play the dominant role as persistent innovators (cf. Cefis and Orsenigo, 2001; Granstrand et al., 1997; Malerba and Orsenigo, 1996; Pavitt, 1986). Several authors have also suggested that investment in complementary assets and capabilities support future innovation (Jacobides et al., 2006; Teece, 1986).

In contrast, competence-destroying discontinuities fundamentally change the knowledge and skills required to develop and produce a product and, therefore, make existing knowledge obsolete (Tushman and Anderson, 1986). Competence-destroying innovations tend to be introduced by new entrants and also lower the barriers to entry for other new firms, since 
previous competence-based competitive advantages are removed when existing competence becomes obsolete (Anderson and Tushman, 1990; Murmann and Frenken, 2002). These innovations are also associated with major changes in industry leadership, favouring new entrants at the expense of incumbents (Tushman and Anderson, 1986). Industry incumbents tend to be handicapped by their previous successes with the old technological paradigm (Tushman and Anderson, 1986); their existing skills, abilities and ways of operating constrain their actions and make it difficult to respond effectively (Abernathy and Clark, 1985; Leonard-Barton, 1992; Macher and Richman, 2004).

\subsection{Market-based explanations of creative destruction}

Market-based explanations of the competitive outcomes of discontinuous change focus on the impact on performance trajectories and industries of a different dichotomy of innovations: sustaining innovations and disruptive innovations respectively.

Sustaining innovations reinforce the established product performance trajectories in an industry (Christensen and Rosenbloom, 1995), by giving existing customers in mainstream markets something more or better in the performance attribute they already value (Bower and Christensen, 1995; Christensen, 1997/2003; Christensen and Bower, 1996). They build on established value networks and, therefore, require no change in the innovating firm's strategic direction (Christensen and Rosenbloom, 1995; Rosenbloom and Christensen, 1994).

Industry incumbents are not always the first to commercialize sustaining innovations, (Christensen et al., 2002), but they will eventually take the lead in all sustaining innovations regardless of whether they are competence-enhancing or competence-destroying (Christensen and Rosenbloom, 1995): “... rarely have even the most radically difficult sustaining technologies precipitated the failure of leading firms” (Christensen, 1997/2003, p. xviii).

In contrast, disruptive innovations imply a different package of performance attributes than those provided by mainstream technologies and valued by existing customers (Bower and Christensen, 1995). ${ }^{1}$ They also tend to redefine the level, rate and direction of performance improvements in an industry (Christensen and Rosenbloom, 1995). When these innovations are first introduced, they tend to underperform in the performance attributes most valued by

\footnotetext{
${ }^{1}$ Christensen et al. (2002) describe disruptive innovation as a strategy that companies can choose to turn ideas into plans for new growth businesses. This perspective is, however, quite different from that presented in most of the literature on disruptive innovation, which rather takes the perspective of incumbent firms faced with the threat from disruptive innovation. In this paper the focus in on the latter perspective.
} 
mainstream customers (cf. also Rosenberg, 1972). Therefore, they will only attract niche customers in small or emerging markets that value their nonstandard performance attributes (Adner, 2002; Bower and Christensen, 1995), or the price-sensitive low end of the mainstream market (Christensen et al., 2003; Govindarajan and Kopalle, 2006). However, over time the disruptive innovation will improve more rapidly than the established technology with regards to mainstream performance attributes, making it performance-competitive also in the mainstream market (Christensen and Bower, 1996). ${ }^{2}$ It can then "invade” the mainstream market (Bower and Christensen, 1995) and even displace its established technology (Adner, 2002).

A central element of this framework is the idea of performance overshooting. According to Christensen (1997/2003), firms generally improve technologies faster than their customers need or ultimately are willing to pay for. The invasion from below is facilitated by such overshooting by incumbents' technologies; when product performance is higher than what the market demands, customers will no longer make product choices based on differences along established performance parameters, but will turn their attention to alternative parameters. Once the main performance requirements of mainstream customers are satisfied, they will therefore embrace the disruptive innovation based on the new attributes it offers, e.g. reliability, convenience or cost (Christensen et al., 2001).

Disruptive innovations are most often pioneered by new entrants (Bower and Christensen, 1995) and tend to be ignored initially by incumbents, for whom they are financially unattractive relative to existing profit models and competing investment alternatives (Christensen, 2006). Because disruptive technologies are inferior to mainstream products in the beginning, the leading companies' most attractive customers typically will not use them (Christensen et al., 2001), and these firms will find it very difficult to devote sufficient resources to develop solutions for smaller low-margin segments, especially when such projects compete with initiatives addressing the needs of known and powerful customers (Bower and Christensen, 1995). ${ }^{3}$

\footnotetext{
2 "Performance-competitive" does not necessarily mean that the performance is at par with that of the established technology; it merely has to be sufficient to satisfy mainstream customers (Adner, 2002; Govindarajan and Kopalle, 2006).

${ }^{3}$ Incumbents may be particularly inclined to overlook innovations that diffuse from low-end market segments upward toward high-end segments (Schmidt and Druehl, 2008).
} 
When the disruptive innovation starts to invade the mainstream market, incumbents will realise the threat, but by then it is often too late and the pioneering new entrants will come to dominate the market (Bower and Christensen, 1995; Christensen and Rosenbloom, 1995). This is a pattern of change that "can occur in any product or service market” (Christensen et al., 2004, p. 270). The main reason is that disruptive innovations require incumbents to rethink their business models (Christensen, 2006) and to establish new value networks (Rosenbloom and Christensen, 1994). In essence, the attacker's advantage thus stems from the inability of incumbent firms to change strategies (Rosenbloom and Christensen, 1994). This implies that disruptive innovation is a relative concept: "something that is disruptive in one company can have a sustaining impact on another” (Christensen et al., 2001, p. 94; see also Christensen, 2006).

\subsection{Predictions of competitive outcomes: a synthesis}

The competence-based and market-based explanations make somewhat different predictions about the circumstances under which incumbents might lose their competitive positions in the wake of discontinuous technological change. Still there is an agreement that if incumbents lose their positions, they lose them to new entrants. The explanation for the attacker's advantage is similar in both approaches: incumbents are unable or unwilling to respond due to organizational, technological and strategic inertia and therefore allocate insufficient resources in response to the threat. More specifically, incumbents lose their positions because their old competences are destroyed or because the current performance trajectory and value network are disrupted as new performance attributes replace existing ones as the prime basis for competition.

Hence, the general prediction is that industry incumbents will be seriously threatened by technological discontinuities that are disruptive or competence-destroying. Under such circumstances, competence-based as well as market-based explanations predict that innovations will be pioneered by new entrants which will take market shares form incumbents. Conversely, sustaining and competence-enhancing technological discontinuities are predicted to reinforce the competitive positions of incumbents; there will be few successful new entrants and incumbents will master any innovation challenges they are faced with. Implicitly, both approaches, thus, assume that the absence of new entrants is a key indicator of industrial stability and the persistence of industry incumbents. 


\section{Research design}

\subsection{Case selection}

As noted by Gerring (2008), case study methodologies have been used both to test existing and to generate new theories. Depending on the purpose, different principles may be applied for selecting the cases. In this paper we seek to further develop the understanding of discontinuous innovation by critically examining the predictions of existing attackers' advantage theories, and by developing a complementary approach for understanding discontinuous innovation processes in specific types of industries. For this purpose, we have theoretically sampled two industry cases: the gas turbine industry and the car industry (in particular power trains). These industry cases have two characteristics which make them suitable for the purpose of this paper:

(1) Both industries have been characterized as Schumpeter Mark II industries, i.e. industries with a concentrated and rather stable population of innovators (cf. Breschi et al., 2000). This suggests on the one hand that incumbent firms in these industries should be competent innovators that are not easily shaken by 'normal' patterns of innovation, and on the other hand that they might be especially vulnerable to discontinuous technological change.

In both industries, there have also been predictions that technological discontinuities in the form of competence-destroying and potentially disruptive innovations would threaten the market positions of incumbent firms. In the gas turbine industry, incumbents were predicted to be challenged by new entrants developing microturbines. For example, management consultant company Arthur D. Little (2000) and Christensen et al. (2001, p. 93) both explicitly identified microturbines as a potentially disruptive innovation and Christensen (2001, p. 13) argued that microturbines "could prove to be very disruptive.” In addition, Hart (2005) predicted that the disruptive characteristics of microturbines and other distributed generation technologies would create opportunities for new entrants to serve the needs of the users much better than incumbent players in the energy sector. In the car industry, Christensen (1997/2003) argued that "electric vehicles have the smell of a disruptive technology” (p. 239) and that “... the electric vehicle is not only a disruptive innovation, but it involves massive architectural reconfiguration ... that must occur ... across the entire value chain ...” (p. 252) (cf. also Aggeri et al., 2009; Dyerson and Pilkington, 2004; Sierzchula et al., 2012). The two industries can, thus, be described as 
'typical' cases of industries on the verge of creative destruction, suitable for confirming or disconfirming the theory of the attacker's advantage (cf. Seawright and Gerring, 2008).

(2) Both industries have experienced (or are currently experiencing) discontinuous change of a very different kind than the predicted attacker's advantage: hardly any new significant entry but instead intensified competition between incumbents. These developments could be interpreted as competence-enhancing and sustaining innovation, since established competences and basic performance attributes remained important. However, the effects on incumbents' competitive positions were still dramatic. In the gas turbine case, industry leadership changed and major incumbents were forced out of the industry; in the car case industry leadership is being profoundly challenged after 80 years of stability. The two industries can, therefore, be seen as 'deviant' cases, i.e. cases that demonstrate a surprising pattern in relation to the general understanding of technological discontinuities, and, therefore, are useful when searching for alternative explanations (cf. Seawright and Gerring, 2008).

The selected cases, thus, represent two important industries where the predictions of existing frameworks on competence-destroying and disruptive innovation have not materialized, while at the same time the innovation processes actually taking place have been far more dramatic and difficult for incumbents to handle than existing theories tend to assume.

The case studies focus on innovations in core subsystems, since such innovations are likely to have the most significant commercial implications (Gatignon et al., 2002). In order to capture both the predicted and the actual challenges for incumbent firms, we study two sub-cases in each industry: one competence-destroying and potentially disruptive innovation (microturbines and electric vehicles (EVs) respectively), and one sustaining and competenceenhancing innovation (combined-cycle gas turbines (CCGT) and hybrid-electric vehicles respectively).

Our investigation of the competence-destroying and potentially disruptive innovations includes new entrants and their fates as well as the actions taken by incumbents in face of the potential threats (although all incumbents did not respond explicitly), whereas the investigation of the competence-enhancing and sustaining innovations primarily includes incumbents as there were no, or very few, new entrants. The study of the car industry is delimited to the established core manufacturers from Europe, Japan and the U.S. China has 
recently become the largest single car market, but in spite of this strong growth, China has not produced any major car manufacturer with a distinctive innovation strategy and international presence, and the Chinese market continues to be dominated by foreign manufacturers and their local affiliations, with Volkswagen as No. 1, and GM as a rather distant second. Despite high ambitions, Chinese firms have also failed to develop cost competitive alternative power trains, electric or hybrid-electric, and are therefore not included in the section on EVs (cf. McKinsey, 2012; Yao et al., 2011).

\subsection{Case characteristics and comparability}

The industries are similar in that they both supply composite, engineered products. The development of such products involves design, engineering, sourcing and integration of both physical components and sub-systems as well as the integration of a diverse set of scientific and engineering knowledge bases and capabilities (Rycroft and Kash, 2002). Improving the performance of combustion engines, for example, requires a combination of technological competencies from fields of knowledge as diverse as mechanics, materials, heat transfer, combustion, fluid flow, electronics and computer-aided design (Granstrand et al., 1997). The requisite knowledge may be related to individual components and sub-systems, but also to architectural knowledge, i.e., knowledge of how to integrate various components and relevant engineering knowledge bases (Henderson and Clark, 1990; Takeishi, 2002).

But the industries also differ along several dimensions:

- Product type and production scale. The gas turbine industry is characterized by customized, small-batch production of complex capital goods, whereas the car industry is characterized by standardized mass production of complex consumer goods.

- Market characteristics. The gas turbine industry is strongly global with similar customer demands across major markets. The car industry is also global in the sense that major manufacturers operate globally, but markets are strongly influenced by national and regional regulations and customer demands, with important differences between North America, Japan and Europe. The fates of car manufacturers are also influenced by direct government interventions, such as incentives in support of specific types of vehicles or bailouts to avoid bankruptcies of national icons. 
- Time perspective. The gas turbine case can be considered as a closed case, in the sense that the studied “era of ferment” (Anderson and Tushman, 1990) has passed. By contrast, the competition in the car industry between firms and between technologies is still ongoing and uncertainty remains high.

Following the taxonomy outlined by Pavitt (1984), the car industry would be categorized as a scale-intensive industry, whereas the gas turbine industry would be included in one of the sectors Pavitt identified as an extension of his original taxonomy: “expensive capital goods”. The two industries can therefore be expected to display different patterns of innovation.

\subsection{Data sources}

The strategies for data selection and collection have been adapted to the differences between the sub-cases. Table 1 provides an overview of the types of data collected, and the different indicators and sources used.

Annual reports have been used extensively, especially in the CCGT sub-case. The reports from GE were especially valuable because of their level of detail and frankness regarding the company's “after-delivery problems” (maybe because GE was the most successful incumbent in solving them). Annual reports were also used to get financial data in the electric vehicle sub-case, and for microturbines, where the leading manufacturer Capstone provided extensive information to infuse confidence among investors even when the business was developing slowly. Market data were collected from several different sources. In the CCGT sub-case, we had access to a database containing global market orders compiled by Jim Watson and colleagues at SPRU (see also Bergek et al., 2008). In the microturbine sub-case, sales performance data for the active companies were retrieved from their annual reports (see also Magnusson, 2003). In the car industry, product announcements by manufacturers were complemented by publicly available sales statistics from, e.g., the U.S. Department of Energy. In this industry, the study could also benefit from a range of publicly available business publications and trade journals: professional publications such as Automotive News as well as popular magazines with their frequent testing of new products. Trade press was also an important source of information about technical performance and product launches in gas turbine industry.

These secondary data were complemented by interviews with technical experts and R\&D managers. At the incumbents, these interviews focused on technical forecasts and 
comparisons, as well as issues related to future product development; at new entrants they also covered commercial prospects for new offerings. Structured interview guides were prepared based on careful studies of the relevant sub-industries and firms. The analysis of this specific type of expert interviews did not build on formalized coding protocols; more important, in particular in the car industry, was to check statements related to performance and market achievements with identifiable public sources, e.g. product performance tests and sales data. This is related to the crucial problem of evaluating trends and projections in an industry surrounded by so much publicity and hype regarding new technologies as the car industry. The bold predictions in the 1990s, also from leading car industry executives, concerning a rapid transition to hydrogen-based vehicles here served as a cautionary tale (cf. Bakker, 2010).

Table 1. Overview of data types and sources

\begin{tabular}{|c|c|c|c|c|c|}
\hline $\begin{array}{l}\text { Industry } \\
\text { case }\end{array}$ & Sub-case & Interviews & $\begin{array}{l}\text { Annual } \\
\text { reports }\end{array}$ & Trade press & Other sources \\
\hline \multirow[t]{2}{*}{$\begin{array}{l}\text { Gas } \\
\text { turbine } \\
\text { industry }\end{array}$} & $\begin{array}{l}\text { Micro- } \\
\text { turbines }\end{array}$ & $\begin{array}{l}\text { Corporate manager ABB } \\
\text { (2000), R\&D manager } \\
\text { Alstom (2001), R\&D } \\
\text { managers, Marketing } \\
\text { managers and CEOs at } \\
\text { Capstone (2001, 2002) } \\
\text { and Turbec (2001), } \\
\text { Customers and Energy } \\
\text { experts (2001, 2002) }\end{array}$ & $\begin{array}{l}\text { Sales } \\
\text { performance }\end{array}$ & $\begin{array}{l}\text { Technical } \\
\text { performance }\end{array}$ & \\
\hline & CCGT & $\begin{array}{l}\text { Marketing managers, } \\
\text { Engineers and R\&D } \\
\text { managers at ABB (1998, } \\
\text { 1999) and Siemens } \\
(2004,2008)\end{array}$ & $\begin{array}{l}\text { Strategies, } \\
\text { challenges }\end{array}$ & $\begin{array}{l}\text { Technical } \\
\text { performance } \\
\text { Product } \\
\text { launches }\end{array}$ & $\begin{array}{l}\text { Database on } \\
\text { global orders }\end{array}$ \\
\hline \multirow[t]{2}{*}{$\begin{array}{l}\text { Car } \\
\text { industry }\end{array}$} & $\begin{array}{l}\text { Electric } \\
\text { vehicles }\end{array}$ & Technical experts & $\begin{array}{l}\text { Financial } \\
\text { data }\end{array}$ & $\begin{array}{l}\text { Sales \& prices } \\
\text { Product tests } \\
\text { Market data }\end{array}$ & $\begin{array}{l}\text { Product } \\
\text { announcements } \\
\text { by manufacturers } \\
\text { Research reports } \\
\text { (case studies of } \\
\text { new entrants) }\end{array}$ \\
\hline & $\begin{array}{l}\text { Hybrid- } \\
\text { electric } \\
\text { vehicles }\end{array}$ & $\begin{array}{l}\text { Hybrid R\&D managers } \\
\text { at Toyota (1999, 2006), } \\
\text { GM (2007), VW (VP } \\
\text { R\&D 2008) }\end{array}$ & & $\begin{array}{l}\text { Sales \& prices } \\
\text { Product tests } \\
\text { Market data }\end{array}$ & $\begin{array}{l}\text { Technical reports } \\
\text { USDOE sales } \\
\text { statistics }\end{array}$ \\
\hline
\end{tabular}




\section{Discontinuous technological change in two industries}

\subsection{The gas turbine industry}

\subsubsection{Microturbines: a distributed technology that failed to disrupt}

In the early 2000s, there were high hopes that the concept of distributed electric power generation would represent a major break with the established structure of electric power supply in most western economies. Instead of relying on a few centrally located power plants and long-distance transmission lines, distributed electricity systems would comprise a large number of generators on the user side of the distribution grid, producing power locally supported by smart grids. This would result in reduced power transmission losses and enable quick, incremental capacity additions to match demand.

The concept included both mature technologies such as internal combustion engines and more novel ones such as photovoltaic solar cells, fuel cells and microturbines. Among these technological options, the microturbine stood out by its simple design, comprising only one moving part, and microturbine manufacturers argued that this was the only new small-scale power generation technology that had reached a competitive cost level (Magnusson, 2003). The microturbine was also flexible in terms of the fuel source; it could use a variety of hydrocarbon fuels, e.g. natural gas, biogas, kerosene, propane and diesel.

There were also several drawbacks, however. In terms of the most important performance parameter for thermal power generation - electrical efficiency - the microturbine only achieved half the level of the combined cycle gas turbine, which was the dominating largescale technology. Moreover, the microturbine featured significantly higher capital cost per unit of power generation capacity than the large turbines. However, the microturbine offered value in other performance attributes, such as flexibility and a potential for simple combined heat and power (CHP) applications, in which the excess heat from the power generation would be used to heat residential buildings, hotels, offices, swimming pools etc. Provided that standards were available for interconnection with the electric grid, an installation could be completed within a few weeks. This could be compared with the several years of planning, negotiations, preparations and construction work needed for a new large power plant. With a standardized product configuration, the microturbine design was also much simpler and due to the much smaller unit size, the unit cost of a microturbine generator was much lower than that 
of a complete combined cycle gas turbine power plant. The microturbine was, thus, more flexible and convenient than the large scale technology.

Located in southern California, the new technology based firm Capstone Turbine took the role as the leading microturbine manufacturer, entering the market in 1998. In the early 2000s, Capstone offered microturbine based solutions for a broad range of applications including resource recovery (using waste gases from landfills, sewage plants, wellheads etc.) hybridelectric vehicles (range extender for battery-electric buses), CHP (combined heat and power generation) and secure power (auxiliary power units to be operated in case of power outage). Other manufacturers entered the market, such as the start-up Turbec (Sweden), emanating from a joint venture between the large scale turbine manufacturer $\mathrm{ABB}$ and the jet engine manufacturer Volvo Aero. This firm was set-up in 1998 with the intention to commercialize results from joint R\&D activities since the early 1990s. The British new technology based firm Bowman and the large and diversified American firm Ingersoll-Rand also entered the market in the early 2000s. Moreover, established manufacturers such as Alstom and GE announced that they pursued $\mathrm{R} \& \mathrm{D}$ in the area of microturbine technology (Magnusson et al., 2005).

According to Christensen et al (2002) there are two alternative strategies for market entry with potentially disruptive technologies, either via the low-end tiers of existing markets or via new markets. To identify the most viable strategy, these authors offer a number of "litmus tests”. To enter via the low-end tiers of existing markets, it is necessary to pass two litmus tests. First, products on the existing market need to overshoot the level of performance which the least demanding customers are willing to pay for. Second, new entrants need to create a business model which is based on a low-cost strategy. If the firm instead enters via new markets, it should 1) “target customers who in the past haven't been able to 'do it themselves' for lack of money or skills”, 2) “aim at customers who will welcome a simple product” and 3) "help customers do more easily and effectively what they are already trying to do" (Christensen et al., 2002pp. 24-25).

The high capital cost per unit of power generation capacity made it difficult for microturbine manufacturers to adopt a low-cost strategy. Moreover, fuel expenses were still a determining factor for the operating costs of thermal power generation and electric power producers would hardly adopt technologies with significantly lower efficiencies than other available technologies. The microturbine manufacturers therefore preferred to enter via new markets. 
They explicitly targeted customers whose core business was completely different from large scale electric power generation, e.g. hotels, restaurants, offices and small manufacturing firms. Having neither the skill, nor the money or ambition to become large power producers, these customers appreciated the low unit cost, simple design and easy installation of the machine. By means of the microturbine, it was possible for these customers to ensure a stable access to electricity, and by running the machine at peak-load, when electricity prices were high; the microturbine offered a possibility to reduce the sensitivity to volatile electricity prices. Due to the Californian energy crisis in the early 2000s, this had become a particularly urgent issue on the home market for the leading microturbine supplier Capstone. Since the microturbine enabled quick capacity extensions with high systems efficiency if used in CHPapplications, policy makers also supported commercialization of the technology through financial incentives.

Bower and Christensen (1995, p. 52) argue that also large incumbent firms can manage disruptive innovation, provided that they "keep the disruptive organization independent”. $\mathrm{ABB}$, the only incumbent turbine manufacturer which entered the market with a microturbine, strictly followed this advice. They established Turbec as an independent business unit, separated both geographically and organizationally from its large scale parent. However, in 2004 the microturbine business had not taken off and ABB sold off Turbec to the Italian firm API Com S.r.I., which still by 2011 had very limited sales. The second large firm to enter the market with a microturbine CHP unit, American Ingersoll-Rand, was more persistent, but in 2011 also this firm divested their microturbine business. Other firms that announced activities in microturbine technology in the early 2000s, e.g. GE, Alstom and Bowman, either did not present any products or failed to get any market foothold. In 2011, ten years after the initial optimism and thirteen years after the first product launch, Capstone was the only microturbine manufacturer that actually had a position on the market. Between 2007 and 2011 Capstone increased its revenue almost four-fold, from 21 to 82 million USD, but still struggled to make any profit. Moreover, its deliveries in terms of installed power were marginal when compared to the leading manufacturers of large turbines for electric power generation. ${ }^{4}$

Both the new entrants (such as Capstone) and some incumbent gas turbine manufacturers (such as ABB through its start-up Turbec) initially believed in the disruptive potential of microturbines and some even incorporated the disruptive innovation framework as part of

\footnotetext{
${ }^{4}$ Capstone's booked orders for the fiscal years 2010 and 2011 were 77.2 MW and 91.9 MW respectively. This can be compared to the size of one single large-scale gas turbine (50-2,000 MW, see Table 1).
} 
their marketing strategy (cf. Capstone Management, 2009; Murelio, 2000; Tanner, n.a.). The classification as a disruptive technology meant that they did not have to worry too much about the inferior efficiency of their product. Following the logics of disruption, the value of existing performance parameters would diminish, and new parameters would become more valuable. The new markets would grow and eventually erode the existing main markets for large turbines. The entry via new markets would set these disruptive processes into motion. This did not happen.

During the time it had been available on the market, microturbine technology developed very slowly both in terms of costs and electrical efficiency. In 2011, its efficiency performance, which remained the key performance parameter on main markets, was still only half of the performance of large-scale CCGT and the capital cost per $\mathrm{kW}$ between two and three times as high (see Table 2). The new markets targeted by microturbine manufacturers were severely limited in size and did not grow at a pace that resulted in any erosion of the main market for large turbines. Thus Capstone remained a niche player and the microturbine remained a niche technology that did not pose any real threat for industry incumbents.

Table 2. Performance characteristics of microturbines and combined cycle gas turbines

\begin{tabular}{lcccc}
\hline & \multicolumn{2}{c}{ Microturbine } & \multicolumn{2}{c}{ Combined cycle gas turbine } \\
& 2002 & 2011 & 2002 & 2011 \\
\hline Typical size range (MW) & $0.03-0.4 \mathrm{MW}$ & $0.03-0.25 \mathrm{MW}$ & $50-2,000 \mathrm{MW}$ & $50-2,000 \mathrm{MW}$ \\
Capital cost (USD /kW) & $1,200-1,700$ & $1,290-1,410$ & $500+$ & $500+$ \\
$\begin{array}{l}\text { Thermal electrical } \\
\text { efficiency }\end{array}$ & $14-30 \%$ & $22,6-33 \%$ & $48-57 \%$ & $50-60 \%$ \\
\hline
\end{tabular}

Sources: Greene and Hammerschlag (2000); Smith (2002); California Energy Commission (2012); EPA (2008); Capstone (2011)

Proponents of disruptive innovation theories may argue that disruption is only a matter of time (cf. Nair \& Ahlstrom, 2003). Clearly, there is a limit at which the cost for additional improvements on mainstream performance parameters will exceed the benefits. This limit will determine what is "good enough" on mainstream markets. According to this argument, opportunities for disruption will emerge, when the large turbines reach this plateau. However, such an argument is of limited use for microturbine manufacturers. Given the physical limitations of the technology and the modest efficiency improvements during its first decade on the market, it is unlikely that microturbine technology ever will become "good enough" in a comparison with large combined cycle gas turbines. 


\subsubsection{Competition in large gas turbines: a life and death race for incumbent firms}

While disruptive innovation theorists focused on the prospect of microturbines, the real industrial drama was played out in an intensified technological competition among incumbents in the development of even more efficient and powerful large gas turbines. Advanced gas turbines are a key building block in combined cycle power plants, which combine gas and steam turbines to achieve electrical efficiencies that are almost $50 \%$ higher than those of other fossil-fuel power stations. Whereas the total market for electric power generation equipment grew very slowly in the late 1980s and early 1990s, sales of advanced gas turbines for combined-cycle applications suddenly took off when GE introduced its innovative 'Frame 7F' in 1986. With Frame F, GE launched a combination of architectural and component innovations, which increased the thermal efficiency of combined-cycle power plants to 54 percent, far above that of any other fossil-fuel technology.

From just a small fraction of installed power generation capacity in 1987, combined-cycle gas turbines increased their market share to over 35 percent in 1993. To cope with this expansion and the challenge from GE, all its competitors invested heavily. Westinghouse was the first to respond with its own F turbine, developed in collaboration with Mitsubishi. Siemens followed with its V94.3. This new machine comprised many advanced component features, such as supersonic blades in the compressor and cooling in three of the four turbine blade stages. It was larger (200 MW) and also slightly better in terms of thermal efficiency than GE's 7F turbine. ABB was the last of the incumbents to launch a turbine comparable to GE's Frame $7 F$, introducing the GT13E2 turbine. Only one year later, however, ABB took the technological lead by introducing their GT24/26. This was a very different machine, featuring a new sequential combustion chamber design and a new type of compressor, which gave another 2 percentage point increase in thermal efficiency. It sold very well initially but after a few years ran into disastrous technological difficulties. The other companies launched new generations with similar thermal efficiencies: Westinghouse’s 501G in 1994, Siemen's V84.3 in 1995, and GE's Frame 7G in 1995. Unlike ABB's machine, these turbines were largely based on component improvements such as blade design, materials and cooling.

All companies that started in the large gas turbine race were, thus, able to launch successive generations of turbines at about the same rate and performance. However, all of them also suffered from difficult periods of customer-experienced problems. During the development process, the firms had introduced a range of new methods, new materials and new 
manufacturing technologies. This opened up possibilities in terms of more heat-resistant turbine blades, more optimized designs and more intricate cooling systems. But the use of e.g. elevated compression ratios, higher turbine inlet temperatures and lean combustion processes to reach higher efficiencies and lower $\mathrm{NO}_{\mathrm{x}}$ emissions resulted in entirely new problems, which the engineers could not foresee.

According to $\mathrm{R} \& \mathrm{D}$ managers, developing new gas turbines requires a truly multidisciplinary process, and if one discipline takes a commanding role without considering the implications as understood from other disciplinary perspectives, the result could be a disaster. Balancing and integrating expert knowledge is not the only challenge in this development process. A factor making innovation in advanced gas turbines particularly uncertain is the very high unit cost of a new machine and the large facilities needed to run full-load tests of new turbines. Thus it is difficult for engineers to verify the real-world performance and reliability of their new product. The problems therefore remained undiscovered when the machines were delivered to the first customers and had to be solved when the turbines had already been commissioned. This means that introducing advanced products was not enough. Dealing with after-delivery problems and upholding high operational reliability was a moment of truth, requiring on-the-field application of both specialized and integrated knowledge. Neither ABB, nor Westinghouse was able to solve their technical problems in a satisfactory way and they both had to exit the entire power generation industry.

As can be seen from Figure 1a, the position of the leading firms on this global market (measured by market shares) was quite even in late 1980s and early 1990s. GE, Siemens, ABB and Westinghouse (together with its partner and licensee Mitsubishi) were the top four competitors. The intense technology battle implied a great challenge for the companies, and their fortunes differed dramatically. Both Westinghouse and ABB were forced to exit the industry, leaving GE as the obvious leader and Siemens as a distant second (see Figure 1b). 


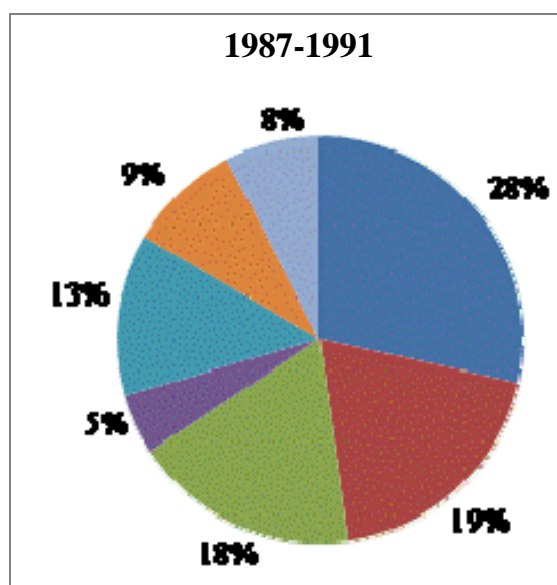

(a)

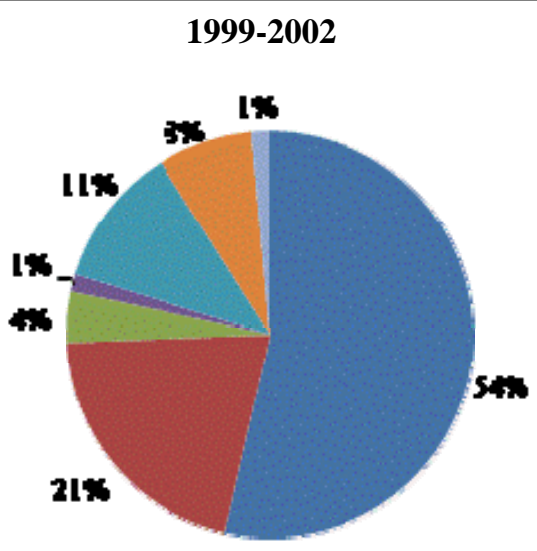

(b)

Note: "GE licensees” include primarily Alstom; “Westinghouse licensees” include primarily Mitsubishi.

Figure 1: Global market share based on total CCGT-orders in 1987-1991 vs. 1999-2002.

From a knowledge and innovation perspective it may be argued that GE was able to master both the creation and the accumulation aspects of its innovation process. The company embedded the creative elements, the Frame F design with its new components, in a broad and deep pool of knowledge and experience. This also provided a basis for its superior problemsolving abilities. ABB on the other hand suffered from a lack of knowledge depth and integrative capabilities at key R\&D positions. Its GT24/26 design with a sequential, two-stage combustion process involved high technical risks which could not be tested in its in-house facilities. In spite of insufficient accumulated knowledge, a risky sales process was launched, without back-up in deep problem-solving abilities. The result was a massive innovation failure. In contrast to ABB, the new V84.3A turbine from Siemens was based largely on its previous products, with increased temperature and airflow to improve efficiency. Pratt \& Whitney also added new knowledge regarding blade designs, high temperature materials, and cooling systems. Siemens subsequently reported vibration problems in its new turbines, and had to allocate significant resources to solve these problems which caused the entire power generation segment to report negative economic results in 1999. However, a few years later the company had solved these problems and could remain a strong number two on the market with a share of just over 20\%. Westinghouse had insufficient depth in CCGT technology, and much of its gas turbine competence pertaining to its original design was transferred to its partner Mitsubishi. Its turbine problems were aggravated by resource constraints due to significant losses in its nuclear power business, caused by litigation costs. Thus, the company 
lacked technological, financial, and managerial resources to participate in the technological race, especially when substantial efforts had to be deployed to solve after-delivery problems.

The race to develop advanced gas turbines for combined cycle power generation is a case of discontinuous innovation that cannot be described according to the attacker's advantage frameworks. Established competences were not destroyed, the main performance parameter, thermal electrical efficiency, prevailed, and no new entrants succeeded. Still, the incumbents had no guarantees for sustaining their position, and two incumbents with a legacy of industry leadership were forced to withdraw from the market because of their failure to innovate on the basis of established technologies. The case of advanced large gas turbines illustrates that intensified technological competition can trigger major industry change, also when it does not entail any disruptive and competence-destroying innovations.

\subsection{Power train competition in the car industry}

\subsubsection{Electric vehicles: a source of creative destruction?}

Electrically powered vehicles are as old as the car industry, but were outcompeted by gasoline cars in the 1910s. However, after 70 years in obscurity they received a new chance in the 1990s when GM unveiled its electric Impact car (Shnayerson, 1996) and California legislated the so-called Zero Emission Vehicles (ZEV) mandate, which required major car manufacturers to introduce emission-free power-trains for an increasing part of their vehicle sales, 2 \% in 1998, 5 \% in 2001, and 10 \% in 2003 (Sperling and Gordon, 2009). Following the ZEV mandate, all incumbents launched battery electric cars, such as GM EV1, Honda EV Plus, Ford Ranger EV, and Toyota RAV4 EV, but none of these were produced in more than 1,500 units. When lawyers engaged by the automotive majors managed to fight back the ZEV mandate in 2002, EV-production ceased at all major car manufacturers and no incumbent tried to continue battery electric vehicles as a commercial operation. ${ }^{5}$

Ten years later, however, a new breed of electric vehicles emerged. Compared to the previous period these vehicles have a commercial orientation and feature important advances in batteries based on lithium-ion technologies, which have inspired optimistic official forecasts of EV penetration, from the U.S. to China. In the U.S., President Obama set the goal in 2009 of a putting one million electric vehicles on the road by 2015 as "a key milestone toward

\footnotetext{
${ }^{5}$ The electric cars were physically destroyed, especially so by GM who only leased its EVs. After being pressured by lobbyists and customers, Toyota made an exception at the end of life of its RAV4 EV and actually sold 300 vehicles.
} 
dramatically reducing dependence on oil and ensuring that America leads in the growing electric vehicle manufacturing industry” (USDOE, 2011). In China, the government set an even more challenging goal: five million electric and plugin hybrid electrics on the road by 2020, with the similar purpose of achieving Chinese leadership in the new promising industry (McKinsey, 2012).

However, despite major investments in product development, production and marketing, sales have remained disappointing on the crucial U.S. market. In 2011, less than 18,000 EVs including plug-ins, were sold in the U.S. (which could be compared with total sales of 12.8 million passenger vehicles this year), and forecasts for 2012 showed a very small increase (Wahlman, 2012). These bleak figures are related to the persistent price and performance limitations of electric vehicles. The EVs launched as a response to the Californian ZEV mandate were highly priced, had severe limitations in range and speed, plus long charging times. Developments in nickel cadmium and nickel metal hydride technologies in the late 1990s and, more recently, in lithium ion-batteries, have created expectations of a breakthrough for EVs. But as shown in Table 3, EV performance has improved only slowly since the 1990s. In spite of massive technological investments, driving range and charging times have not changed significantly, and remain far from conventional ICE-cars or hybrids. Prices are coming down somewhat, however, and with government subsidies EVs could become competitive with advanced conventional cars in specific segments. A niche player such as Tesla Roadster (not in table) stands out with its rapid acceleration, longer driving range (about 200 miles), and relatively short charging time (less than 4 hours) - but so does its price. Thus, the performance of EVs with regard to key performance attributes is still far from competitive enough to make them able to challenge the established technology. 
Table 3. Price and convenience - a comparison of six EVs 1997-2011.

\begin{tabular}{|c|c|c|c|c|c|c|}
\hline & \multicolumn{3}{|c|}{$1997-2003$} & \multicolumn{3}{|c|}{ 2009-2011 } \\
\hline & $\begin{array}{c}\text { Toyota } \\
\text { RAV4EV }\end{array}$ & GM EV1 & Ford EV & MIEV & Leaf & $\begin{array}{c}\text { Renault } \\
\text { Fluence ZE }\end{array}$ \\
\hline $\begin{array}{l}\text { Price (USD, excl. } \\
\text { subsidies) }\end{array}$ & 42,000 & 40,000 & 50,000 & 27,990 & 32,780 & c. $29,000^{\mathrm{a}}$ \\
\hline Range (miles) & $80-120$ & 100 & 75 & 100 & 100 & 100 \\
\hline $\begin{array}{l}\text { Charging time } \\
\text { (hours), std outlet }\end{array}$ & 5 & 8 & n.a. & $6-7$ & 8 & $6-8$ \\
\hline
\end{tabular}

\footnotetext{
${ }^{a}$ Renault who is part of the Nissan-Renault Group pursues a different strategy, where batteries are leased separately.
}

Sources: Prices: trade journals. Actual prices are influenced by subsidies, such as USD 7,500 per EV in federal U.S. subsidies (2011). Range and charging time: company data. Range figures are approximate, and depend on driver behaviour, traffic conditions and the use/non-use of climate systems.

Both incumbents and new entrants have been active in the emerging EV market. One of the EV pioneers was Norwegian Think. Started in 1991, Think developed and introduced a first production model - a compact city car positioned as a convenient alternative to a traditional car - but then went bankrupt in 1998. After being taken over by Ford, Think produced 1,000 cars, before Ford sold out, and production ceased (Roste, 2009). The new owners did not manage to make any business out of the EV production and the company has been haunted by financial problems. In 2011 it went bankrupt for the fourth time in its 20-year history (Bolduc, 2011). When the EV market came to life again in the late 2000s, a number of high-profiled U.S. startups contributed to the high expectations on EVs (Guilford, 2011). From 2008 to 2011, Tesla delivered 2,500 of its roadster before discontinuing production in order to prepare for a new model to be launched in the second half of 2012 (Karlberg, 2011). Fisker raised 860 million USD in private funding and a substantial low-interest USDOE-loan and launched its equally high-priced plug-in Karma in January 2012, but could not secure resources for its second model (Rechtin and Lindsay, 2012). Several other new entrants announced their U.S. entry in 2008-2009, but three years later they had not started production, and a survey in Automotive News showed these firms - Bright, Wheego, Aptera Motors, ZAP Jonway and Coda - to be in dire straits (Webb, 2012). None of the new entrants have, thus, succeeded in challenging the established automakers.

Instead, incumbents have gained the most from the new surge in interest for electric vehicles, beginning in the 1990s. The revival of the EV market in the late 2000s was seen by Japanese incumbents as a possibility to build a new competitive platform after failing to compete with 
Toyota in the hybrid race (see below). Nissan/Renault emerged as a leading proponent of electrical vehicles when it launched the compact Leaf for the mass market in 2010. Nissan produced 10,000 Leaf cars in its first fiscal year ending in March 2011, and planned to produce 50,000 units in the next fiscal year (Greimel, 2011). At Mitsubishi, electrical vehicles became a part of a new growth strategy, which tried to make use of the company's long history in battery research and flexible manufacturing system, where conventional and electric cars are built on the same lines. Mitsubishi produced 1,500 EVs in fiscal 2009, increasing to 5,000 in fiscal 2010 and similar to Nissan, planned major production ramp-ups in 2011-2012 (Orihashi et al., 2010). A range of other industry incumbents started or announced sales of electric vehicles as well (Guilford, 2011): Audi e-tron R8 (2012), BMW Mini EV (2012), Daimler's Smart EV (on sales in 2011), Ford Focus electric (2012), Honda Fit EV (2012), Toyota's new RAV4 electric (2012) and VW E-Up minicar (2013). As noted above, the market success has been limited so far, however. In the first half of 2012, 3,148 Nissan Leaf cars were shipped to U.S. consumers (compared to 3,875 in the same period in 2011), and only 333 Mitsubishi EV subcompacts.

Disruptive innovation theorists (e.g. Christensen, 1997/2003) have argued that the competitive problems of electric vehicles are caused by the "cramming” tendency of established makers, i.e. their strategies to build EVs as similar to conventional cars as possible in order to minimize differences in driving experience for ordinary users. According to this argument, the cramming strategy makes EVs complicated and costly, and also reduces their driving range. However, some of the new entrants, e. g. Think, have tried other strategies, but without much success. Think positioned its car as complementary to conventional cars, which reduced the need for long driving ranges, but failed to gain any substantial market share. Tesla and Fisker have focused high-end market niches with price tags on their first models exceeding USD 100,000. Although their cars have a longer driving range than most other EVs, they are far from entering main markets with cost competitive vehicles. An alternative, "disruptive” strategy is to develop frugal EVs which can target low-end or underserved markets with affordable products. Such markets are actually being targeted by producers of so-called LSEVs, low speed electric vehicles, in both the U.S. and China. Global Electric Motorcars (GEM), the leading American LSEV producer, produced its first vehicle in 1998: a 48-volt 
car that accommodated two passengers and had a top speed of $20 \mathrm{mph} .{ }^{6}$ Ten years later, GEM reported an accumulated production of 40,000 electric vehicles (Automotive News, 2008). In China, even more frugal low-speed electric vehicles have gained popularity in some countryside locations. Similar to the GEM-species, these LSEVs are based on inexpensive lead-acid batteries, but in the Chinese case safety equipment is omitted entirely to reduce the total cost. Chinese national authorities do not recognize them as a road vehicle (and thus owners do not pay any taxes), but provincial authorities in areas where LSEVs are produced have created temporary exemptions. Some observers have presented them as a disruptive innovation, referring to their low cost, utility and simplicity (Wang and Kimble, 2012). In China as in the US, however, the auto market is completely dominated by conventional vehicles, with sales soaring to 14.4 million cars in 2011.

The potential of the makers of low-speed electric vehicles to enter this mainstream market or challenge incumbent automakers is highly debatable. Low cost-products with limited performance may successfully occupy specific niches, but reduced performance and cost are not enough to make a technology a competitive substitute to existing technologies. The critical test is its ability to enter - or erode - main markets and successfully upgrade overall functionality in competition with established products. To do so has been beyond the technical configuration of the low-speed electric vehicles. This is indirectly confirmed by the experience of GEM; although it was owned by Chrysler for more than ten years, it was never used as a basis for any low-end entry into the main car market and nor has its new owner Polestar announced any such ambitions. The explanation seems to be that a vehicle cannot enter main car markets without satisfying a menu of stringent requirements, including speed, efficiency, driving range, convenience, safety, styling, utility, etc. In other words, if car manufacturers pursue cramming strategies, they do it for the simple reason that consumers and regulators are not satisfied with anything less. Better environmental performance and/or lower cost do not in themselves provide any breakthrough competitive advantage.

\subsubsection{The advent of hybrid-electric vehicles: technological competition driven by incumbents}

While electrical vehicles failed to disrupt the car industry, another critical discontinuity did occur. This was triggered by the surprising release in late 1997 of Toyota’s first mass-

\footnotetext{
${ }^{6}$ The National Highway Traffic Safety Administration (NHTSA) supported this venture by designating a new class of motor vehicle, the low-speed vehicle which allowed LSEVs to be driven on public roads if they met certain safety criteria (Wang and Kimble, 2012).
} 
produced hybrid-electric car, Prius I. Initial sales of this sustaining innovation were poor, but the launch of successively refined new models, combined with soaring fuel prices and a rising public awareness of global warming made Prius a symbol of the modern environmental car (Sperling and Gordon, 2009). Toyota sold 88,000 hybrid cars in the U.S. in 2004 and as many as 350,000 three years later. In Japan, Prius became the best-selling car model in 2009 and 2010, and in February 2011, Toyota announced its cumulative hybrid sales had reached more than 3 million vehicles worldwide (Green Car Congress, 2011).

Honda was the first to respond to Toyota’s initiative, launching their Insight model in 1999 and hybrid versions of their standard models Civic and Accord a few years later, gaining a significant share of the U.S. market at that time (see Figure 2a). The American competitors reacted much more slowly and their early $R \& D$ in the field did not generate any new products. However, when hybrids began to gain market shares, GM and Ford ramped up their technological activities and started to present their own hybrid cars. Ford was first, introducing their Escape hybrid in 2004. GM was slower in response, launching their first two hybrid models in 2007 and four additional models in 2008. Chrysler also entered the market in 2008. However the sales of the big three American manufacturers were minuscule compared to those of Toyota. At the same time, Toyota continued to expand its hybrid portfolio by gradually migrating the hybrid technology to the luxury Lexus line, as well as the mass market Camry (in 2006) and the cost-sensitive subcompact Yaris (Prius C) (in 2012). Other manufacturers also entered, including Nissan (2007), Hyundai (2011) and the European manufacturers BMW, Mercedes and Volkswagen (2010-2011). After a late awakening, GM sought to catch up by accelerated efforts to develop technologies for the next round of hybrid evolution, plug-in hybrids, i.e. cars with extended battery capacity that can be charged from the electric grid. Its Chevrolet Volt was launched in 2010. Toyota, however, responded to this leapfrogging attempt a year later by launching a plug-in version of Prius, at a considerably lower price (USD 32,750 as against USD 44,600 for Volt before tax credits and subsidies).

By the end of 2011, fourteen years after the launch of Prius I, all major car manufacturers had a hybrid on their product program. In the U.S. market over 30 different hybrid car models were offered by 9 different manufacturers. However, thus far no one except Toyota had achieved a cost and performance level resulting in any significant sales, giving Toyota an overwhelming market leadership. Whereas sales of Chevrolet Volt reached 16,348 cars in the first nine months of 2012, Toyota Prius sold eleven times more, or 183,340 cars (Rechtin, 2012). Including its full range of Toyota and Lexus hybrids, Toyota owned two thirds of the 
market; forcing Honda, Ford and the other 6 manufacturers to fight for the remaining third (see Figure 2b), in spite of the fact that the 2011 production of Toyota Prius was much reduced because of the March 2011 earthquake in Japan (Colias and Rechtin, 2012).

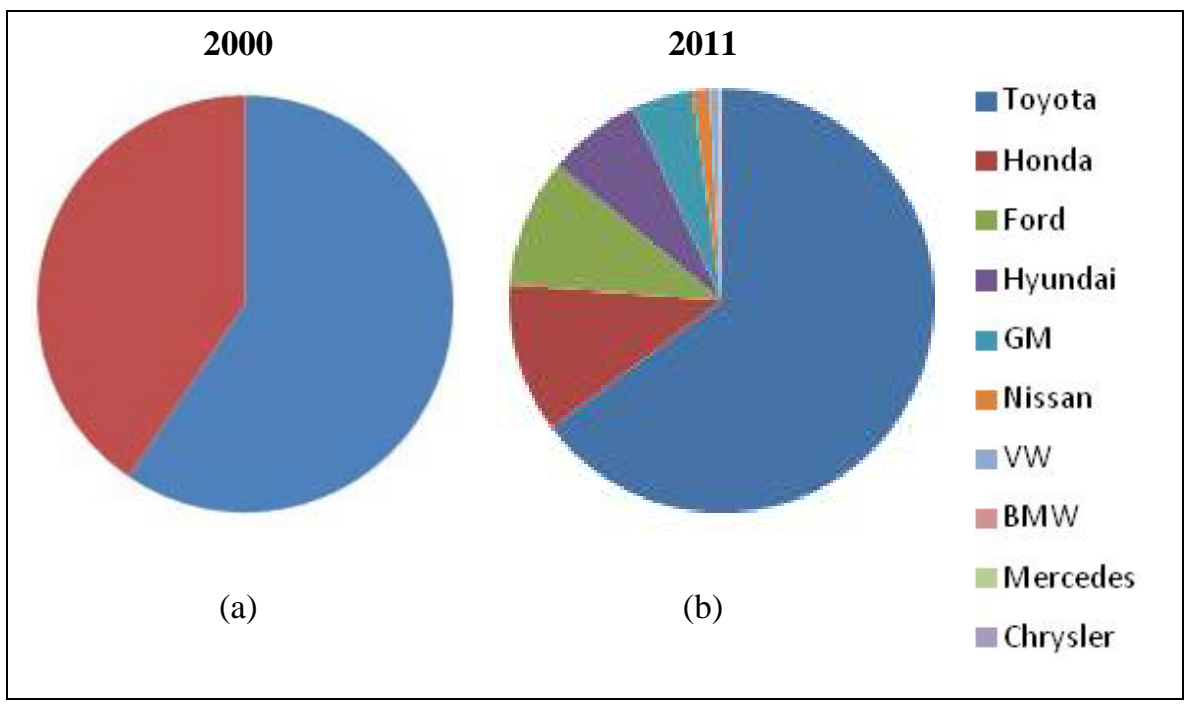

Figure 2 Hybrid car market shares for different car manufacturers on the U.S. market: year 2000 and 2011 (source: USDOE, 2012)

The sales figures for hybrid cars could be compared with the sales numbers for pure electric vehicles presented in the previous section. It is evident that hybrid-electric power trains remain the dominant alternative power-train in the global automotive industry, in spite of the hype surrounding EVs. According to recent estimates of learning rates and price trends of hybrids versus pure electric vehicles, HEVs (including plug-in hybrids) could become the dominant vehicle technology in the next two decades, while pure electrics may require extensive policy support until the late 2020s (Weiss et al., 2012). The main reason for this is that hybrids offer key performance advantages in comparison with EVs in terms of driving range, cost, ease of charging etc.

However, hybrids are considerably more complex than battery electric cars. To combine the virtues of combustion engines and electric drives, innovation is required in new components such as batteries, power electronics and electronic control systems as well as in the powertrain's overall architecture. Judging from price/performance characteristics of hybrids in the U.S. market and their market shares, this is a challenge few established car manufacturers have mastered. The competitors of Toyota have had difficulties not only to design compact and efficient hybrid power trains, but also to build requisite industrial capabilities and reduce cost. When GM introduced its hybrid models, for example, R\&D executives lamented the 
difficulty of reaching a competitive cost level for hybrid car production, claiming that it was virtually impossible to sell hybrids without significant losses (Vice President for Product Engineering, GM Power train Europe, May 2007).

The story of Toyota's hybrid development illustrates the challenges involved in developing a high-performing hybrid-electric car - the significantly increased complexity, the extended need for multi-disciplinarity and the necessity of parallel testing and development - as well as the strategies employed to handle these challenges. The basic rationale for Toyota's strategy is that system level restrictions, such as comfort, safety, serviceability, reliability and cost, make it necessary to optimize all components together. Toyota therefore chose an integrated effort, where both a new architecture and new specialized components were developed inhouse, or in close partnership, in a process where "the Prius teams had to test how each component integrated into the constantly changing system” (Cohen et al., 2009, p. 70). This strategy required accumulation of knowledge of the new component technologies involved in hybrid power-trains, both regarding their properties and manufacture. Many components of the hybrid power-train were originally developed for low-volume applications and not exposed to the process innovation required to reach competitive prices in the car industry. So Toyota became a significant mass producer of electric motors and engaged in intimate collaboration with its supplier of electric vehicle batteries, Panasonic, to develop hybridelectric battery systems to be integrated in the hybrid power-train. The companies formed a joint venture and during the development project Toyota located a significant number of vehicle engineers at Panasonic. At a later stage, Toyota acquired a controlling interest in this joint venture. Toyota's sourcing strategy indicates that when the requisite knowledge base changes, developing new technical insights at the R\&D level does not suffice; the company also needs to access knowledge involved in manufacturing and its cost structures, either by joint ventures or in-house component production.

\section{Analysis: Explaining the competitive outcomes}

\subsection{Why attackers failed}

There are three basic reasons why the attackers and their potentially disruptive innovations failed in both industries: (1) their failure to satisfy established performance demands in main markets, (2) the absence of "overshooting” in the relevant main markets (3) the embeddedness of the studied industries in established infrastructures and institutional frameworks. 
A prime reason why microturbines and electric vehicles failed to capture any significant share of mainstream markets is their undershooting in key performance attributes valued by existing customers. Advantages in zero tailpipe emissions (electric vehicles), and simplicity and flexibility (microturbines) have not sufficed to compensate for their inferior performance in terms of range and flexibility (electric vehicles) and thermal electrical efficiency (microturbines). As described in Section 2, this is the normal state of affairs for many innovations when they are first introduced. However, in contrast to examples of successful discontinuous innovations described in the literature, neither of these technologies has demonstrated sufficient improvements in the established performance attributes. In power generation, microturbines continue to hover around half of the electrical efficiency of large turbines in CCGT-applications, which are continuously improving over the years. And in the car industry, increasing stringencies in emissions and efficiency regulation, both in the U.S., Japan and the EU, have resulted in a new competition among incumbents to upgrade the overall performance, including efficiency, of their established products making them more difficult to compete against and reducing the specific advantages of electrical vehicles.

A second and crucial aspect is that competition in the studied industries has not changed from established to new performance attributes, as suggested in the disruptive innovation framework. In the gas turbine case, this is related to a lack of overshooting. As described in Section 2, the disruptive innovation model assumes that existing suppliers tend to over-serve major market segments in relation to key performance attributes (e.g. storage capacity in disk drive industry). This is described as a general phenomenon, creating a space for new entrants competing on parameters such as cost and convenience. However, in thermal power generation, there has never been any over-shooting in the key performance parameter (electrical efficiency) and with an efficiency rate of 50-60\% in the best combined-cycle applications, the gas turbine industry remains far from saturation. New entrants are always measured on their efficiency performance - and here microturbines fail with a huge margin. In the car industry, the problem for new entrants is the complexity of the established performance trajectory. In the disruptive innovation framework, performance is assumed to be measured along a single critical performance trajectory (cf. Bower and Christensen, 1995). In contrast, car performance is evaluated against a complex set of non-substitutable criteria, including driving experience, styling, fuel efficiency, convenience, functionality, reliability, safety as well as price. To succeed, an innovative product has to improve some core performance attribute (or introduce new ones) without sacrificing the other dimensions. This 
makes it very difficult for new firms to enter based on superiority only in one or two characteristics - they have to offer "good enough" performance on all the other dimensions as well. This also offsets the potentially disruptive effects of any overshooting: even if it can be argued that many car buyers today are over served with respect to driving range or maximum speed and might be willing to substitute reduced emissions for speed, they are not willing to accept lower performance in attributes such as safety and price.

A third reasons for failure is that in both cases the dominant technologies are parts of large socio-technical systems. Any significant change therefore requires major changes in institutions and policies. A wider diffusion of micro-turbines, for example, would need standardized interfaces to the power grid and legal requirements for power utilities to buy power delivered by thousands of distributed generators. Electric vehicles require access to charging stations at convenient locations and new driving patterns among users. Such changes in institutional arrangements and consumer behaviour tend to be even harder to achieve than changes in performance trajectories or firm competences. Hence the infrastructural embeddedness further aggravates the difficulty for new entrants to challenge the industry incumbents.

\subsection{Why incumbents struggled}

As shown in Section 4, the absence of successful attackers did not mean stability in the selected industries. During the periods under study, firms in both sectors faced intensive technological uncertainty and dynamics. The competition in large, advanced gas turbines ended with the exit of two of the four leading incumbents. In the car industry, the competition is still on-going, with an increasing diversity of technological offerings from incumbent firms. Several incumbents have made serious attempts to catch up with Toyota's overwhelming lead in hybrid-electric vehicles - so far, without any success. How can these patterns be explained?

In both sectors, the innovation efforts demonstrate the challenges of building and applying requisite technological competences. In contrast to the framework suggested by Tushman and Anderson (1986), however, the studied industries do not fit into a dichotomy of competenceenhancing vs. competence-destroying innovation. Incumbents struggled even though their existing competences were not rendered obsolete by the discontinuous innovations. A first reason for this was that the pace and scope of innovation in established technologies accelerated and remained a core factor in both industries. The improvement of old technology 
as a response to technological discontinuities is often referred to as the sailing-ship effect (Gilfillan, 1935). Discussing more recent cases, Cooper and Schendel (1976, p. 67) argued that "[i]n every industry studied, the old technology continued to be improved and reached its highest stage of technical development after the new technology was introduced.” But eventually, the new technology carried the day. However, in our cases the old technologies did not leave the stage. Instead they continued to be improved at a rapid pace. A second reason for the struggle among incumbents was the challenge to combine their evolving established technology in complex configurations with new technologies. In the car industry, hybrid electric vehicles combined two very different trajectories: electric power trains and combustion engine technologies. In the gas turbine industry, materials, methods and solutions from the aircraft engine industry were incorporated into CCGT technology. Thus, in both industry cases existing competences - although still important and useful - were insufficient to stay competitive; established firms had to maintain and evolve their deep knowledge in established technologies, while simultaneously searching and acquiring new complementary knowledge, and integrating this with existing knowledge in order to develop and produce optimized product solutions.

\subsection{The case for creative accumulation: a triple challenge}

As the analysis above indicates, attacker's advantage-oriented theories cannot explain our industry cases. They correctly predicted that new entrants would appear in the two potentially competence-destroying and disruptive innovation cases (EVs and microturbines) and that there would be few (if any) new entrants in the competence-enhancing and sustaining innovation cases (HEVs and CCGT). However, in contrast to the predictions of these theories the new entrants were not able to seriously challenge industry incumbents and the main difficulty for incumbents was neither to replace their existing competence base nor to create new business models. The two industry studies thus demonstrate the need for an innovation concept beyond the attacker's advantage. We propose an elaboration of creative accumulation (Pavitt, 1986) as such a concept to understand processes of both accumulation and creativity in complex products industries.

In previous literature, the concept of creative accumulation has been used to highlight the cumulative nature of knowledge processes in so-called mature industries, where the creation of new knowledge builds on existing knowledge and expertise, rather than replacing it (Granstrand et al., 1997; Hobday, 1990). However, whereas this literature presents cumulative 
innovation as incremental, step-by-step enhancements (cf., e.g. Granstrand et al., 1997; Hopkins et al., 2007; Kash and Rycroft, 2002), our notion of creative accumulation stresses the inherent tension between the creativity and accumulation aspects: creativity implies responses “outside of the range of existing practice” (Schumpeter, 1947, p. 150), whereas accumulation implies knowledge creation building on these existing practices.

The creativity aspect is manifested through substantial improvements in cost, performance or quality over previous technologies or the introduction of new performance attributes, based on changes in component technologies, product architectures or both (cf. Henderson and Clark, 1990). The accumulation aspect implies that this type of innovation builds on previous competence, rather than destroys it. However, creative accumulation cannot be described as competence-enhancing in the Tushman and Anderson (1986) sense, since it forces incumbent to go outside their existing knowledge base and search for new competences. Geels (2006) calls this specific type of cumulative innovation process "competence-expanding”, , using it to explain why incumbents in the sewage system regime were able to adjust and reorient themselves:

“[E]xisting knowledge about bricks, pipes, water flows and pumps remained relevant. Additional knowledge had to be developed about how different components were best combined, about costs and benefits of combined or separate sewers, the shape of sewer pipes, material choice, sewer slopes, flow speeds, and soil conditions. But this knowledge had an add-on character, and could be learned by incumbent actors." (Geels, 2006, p. 1078)

In creative accumulation, the existing knowledge base can be seen as a basis for expanding the available choices of firms, rather than a source of inertia (cf. King and Tucci, 2002). As seen above, innovation characterized by creative accumulation also exposes companies to substantial challenges both in terms of mastering "an untested and incompletely understood product or process” (Tushman and Anderson, 1986 p. 444) and of acquiring, integrating and combining new types of knowledge with old ones in novel ways to develop products with substantially improved or changed performance.

Moreover, there is no Archimedean fixed point: both the old and the new domains evolve and interact with each other. This implies that firms cannot choose to follow only one technological trajectory but have to pursue several internal and external trajectories simultaneously, which is a very different challenge from the established understanding of

\footnotetext{
${ }^{7}$ Gatignon et al. (2002) suggest the related concept of "new competence acquisition.”
} 
competence-enhancing innovations. This challenge is even more pronounced in complex product industries. Firms in such industries already have to manage the critical balance between deep component-related knowledge and broad systems-related architectural knowledge (Becker and Zirpoli, 2003; Brusoni et al., 2001; Funk, 2010; Takeishi, 2002). Creative accumulation implies an added challenge of balancing the use of existing knowledge and new knowledge on both these levels.

As illustrated by recent studies in telecommunications sector, creative accumulation is not merely related to technology, as the introduction of new technologies may prompt reconfigurations of industry standard setting processes and value networks (Funk, 2009).

To sum up, creative accumulation requires firms to handle a triple challenge of simultaneously (a) fine-tuning and evolving existing technologies at a rapid pace, (b) acquiring and developing new technologies and resources and (c) integrating novel and existing knowledge into superior products and solutions (Bergek et al., 2011). To meet this challenge, they have to engage in technology search and extended experimentation as a basis for building in-house knowledge and absorptive capabilities (Cohen and Levinthal, 1990), extend their search processes to external sources through close partnering with new suppliers and specialists, and develop technologies and systems that integrate new and existing components and subsystems into functioning products.

\section{Conclusions}

Existing theories on industrial innovation and technological development have presented important explanations of the difficulties confronting leading firms as they attempt to respond to technological discontinuities. Competence-based explanations suggest that technological competencies constitute the prime basis for competition and that the position of incumbents is threatened when new technologies make existing competence obsolete (Tushman and Anderson, (1986). Market-based explanations, on the other hand, suggest that incumbent firms are challenged when new technologies offer novel attributes which alter the rankordering of performance attributes in the market (Christensen and Rosenbloom, 1995; Christensen 1997/2003; Christensen, 2006). These differences notwithstanding, both marketand competence-based explanations argue that the position of incumbents firms is challenged only when technological discontinuities drastically change the prime basis for competition in an industry. 
This paper has analysed discontinuous innovations in two industries, gas turbines and automotive powertrains, representing both the scale-intensive and expensive capital goods types of sectors. The analysis shows the limitations of the existing market- and competencebased explanations when confronted with technological discontinuities in these industries, where no single breakthrough is likely to change the basis for competition. In such industries, technological discontinuities seldom lead to creative destruction, neither disruptive innovation as proposed by Christensen and others, nor competence-destroying innovation as described by Tushman and Anderson.

By developing and extending the concept of creative accumulation (Pavitt, 1986), we have advanced an alternative explanation both to the challenges faced by new entrants trying to compete in capital intensive and complex products industries, and to the challenges threatening incumbents when technological discontinuities intensify competition in these sectors. Creative accumulation highlights the importance of accelerating the development of established technologies, acquiring new technologies and integrating these technologies and attributes with existing ones. Thus firms need to simultaneously develop their existing knowledge and source and integrate new competencies. This perspective explains why potentially competence-destroying or disruptive innovations failed to challenge the industry incumbents in the gas turbine and automotive industries, and why only some incumbents, in spite of the failure of new entrants, managed to survive and improve their competitive positions.

Two main features of creative accumulation contribute to the understanding of why new entrants failed in microturbines and electrical vehicles. First, in industries characterized by creative accumulation, the need to achieve sufficient performance on relevant attributes implies an effective barrier to entry into mainstream markets. Attackers cannot match the incumbents' accumulated knowledge and experience and tend to find it very difficult to develop and manufacture competitive products for main markets. ${ }^{8}$ Second, the depth and breadth of incumbents' knowledge bases enable them to develop effective solutions much faster than new entrants can upgrade their technologies. In the gas turbine and car industries, the creative responses of industry incumbents to each other's product launches forced new entrants to try to hit a moving target. Moreover, accumulated competences and experience

\footnotetext{
${ }^{8}$ This is in line with previous literature suggesting that pre-existing resources play an important role in explaining success entry into new fields. Firms with resource profiles that match the requirements of an industry, i.e. with a smaller "resource gap" (Helfat and Lieberman, 2002), are more likely to successfully enter a new field.
} 
enable incumbents to develop new applications and features to compete head-on with new entrants, if they so choose (cf. Ansari and Krop, 2012).

The need to combine established but evolving technologies with new knowledge and to compete with improved performance along established performance criteria also explains the lack of external attackers in hybrid powertrains and combined cycle gas turbines. In the case of large gas turbines, no new firms entered during the 1990s in spite of a rapidly expanding market involving entirely new customer segments. The car industry has repeatedly witnessed new entrants' endeavors to launch new power-trains, building on specialized technological expertise (e.g., in electrical engineering or fuel cells). To date, however, no new entrant has succeeded in integrating such an expertise with an independent development of established technologies and manufacturing capabilities to build a major market presence.

Creative accumulation with its tension between accumulation and creativity also sheds light on the challenges experienced by incumbents, when competing to develop substantially new turbine and powertrain technologies. Although these innovations could partially build on incumbents' established knowledge bases, the creative aspects of the process had the power to destroy the market position of several firms. In the gas turbine industry, ABB and Westinghouse withdrew from the gas turbine market completely. In the car industry, General Motors was only saved by a government bail-out in 2009 after failures both to keep abreast of the industry's process-based competition on costs, and in the technology-based search for new power-trains.

This demonstrates how difficult it is to innovate persistently and that “... sustained innovative performance is generated and has to be supported by systematic and continuous processes of accumulation of resources and competencies over time” (Cefis and Orsenigo, 2001). Incumbents in the car and gas turbine industries certainly had to develop deep knowledge in their established technologies, when the pace of improvement, innovation and competition increased rapidly. However, in contrast to traditional explanations of competence-enhancing discontinuities, the competence-expanding innovations in these cases also required incumbents to search for and acquire new knowledge, including new external partnerships. Accordingly, firms could not choose to invest only in one technological track but had to develop several tracks simultaneously - and integrate them again and again. The failure of some of the incumbents in the two industries to compete successfully can, thus, be interpreted as a failure to manage the triple challenge of creative accumulation. 


\section{Discussion}

The innovation cases analysed in this paper suggest that the challenges associated with creative accumulation are particularly pertinent for explaining dynamic developments in industries supplying complex products. In such industries, technology constitutes a prime means for competition and an increasing portion of innovations relies on a combination of competences from many different fields. We have analysed two highly different industries, representing both the scale-intensive and capital goods types of sectors to refer to Pavitt (1984). These industries could be expected to display different patterns of innovation. In spite of this, the similarities in overall innovation dynamics, including the failure of entrant firms and the struggle of incumbents, are highly salient and demonstrate the value and relevance of the elaborated creative accumulation concept in an important range of industries.

The challenges of creative accumulation also have organizational dimensions. First, creative accumulation implies difficult decisions regarding sourcing and competence building: should the firm invest in internal $\mathrm{R} \& \mathrm{D}$, product engineering and process/manufacturing engineering, or should it sustain knowledge-generating alliances with outside partners? In the gas turbine case, GE Power Systems benefited from synergies with the jet engine segment within this diversified corporation, in contrast to competitors who had to engage in complex technology alliances, where Siemens succeeded and ABB failed. In the car industry, hybrid development is making electro-technical engineering and battery chemistry new core competences, but partner choice is severely limited due to the oligopolistic nature of this and similar industries. Thus firms need to do strategic sourcing investments and also invest in building capabilities to absorb and integrate knowledge generated in these partnerships.

Second, creative accumulation requires a different organizational setup than that proposed by attacker's advantage-based theories. These theories suggest that managers faced with competence-destroying and potentially disruptive innovations should organize autonomous units to focus on the market niches first appreciating the new technology (Bower and Christensen, 1995; Christensen, 1997/2003) and to pursue this focus without disturbances from operations relying on established knowledge or networks (O'Reilly and Tushman, 2004; Tushman et al., 2010). However, the validity of this advice can be questioned in cases of creative accumulation, which involves the triple challenge of developing knowledge embedded in existing organizations, searching for new knowledge outside established firm boundaries and repeatedly combining these diverse sources of knowledge. An important topic 
for future research would be to investigate organizational solutions which can sustain prolonged efforts of such dynamic integration, which is a key feature of creative accumulation.

\section{Acknowledgements}

Financial support from Riksbankens Jubileumsfond, and helpful comments from members of the KITE research group and two anonymous reviewers are gratefully acknowledged.

\section{References}

Abernathy, W.J., Clark, K.B., 1985. Innovation: Mapping the winds of creative destruction. Research Policy 14, 3-22.

Adner, R., 2002. When Are Technologies Disruptive? A Demand-Based View of the Emergence of Competition. Strategic Management Journal 23, 667-688.

Aggeri, F., Elmquist, M., Pohl, H., 2009. Managing learning in the automotive industry - the innovation race for electric vehicles. Int. J. Automotive Technology and Management 9, 123147.

Anderson, P., Tushman, M.L., 1990. Technological Discontinuities and Dominant Designs: A Cyclical Model of Technological Change. Administrative Science Quarterly 35, 604-633. Ansari, S., Krop, P., 2012. Incumbent performance in the face of a radical innovation: Towards a framework for incumbent challenger dynamics. Research Policy 41, 1357-1374. Arthur D. Little, 2000. Opportunities for Micropower and Fuel Cell/Gas Turbine Hybrid Systems in Industrial Applications. Arthur D. Little, Inc., Cambridge, Massachusetts. Automotive News, 2008. Corrections. Automotive News November 17. Bakker, S., 2010. The car industry and the blow-out of the hydrogen hype. Energy Policy 38, 6540-6544.

Becker, M.C., Zirpoli, F., 2003. Organizing new product development: Knowledge hollowing-out and knowledge integration - the FIAT Auto case. International Journal of Operations \& Production Management 23, 1033 - 1061.

Bergek, A., Berggren, C., Magnusson, T., 2011. Creative Accumulation: Integrating New and Established Technologies in Periods of Discontinuous Change, in: Berggren, C., Bergek, A., Bengtsson, L., Söderlund, J., Hobday, M. (Eds.), Knowledge Integration and Innovation. Critical challenges facing international technology-based firms. Oxford University Press, Oxford, pp. 246-273.

Bergek, A., Tell, F., Berggren, C., Watson, J., 2008. Technological capabilities and late shakeouts: industrial dynamics in the advanced gas turbine industry, 1987-2002. Industrial and Corporate Change 17, 335-392.

Bolduc, D.A., 2011. Norwegian EV maker Think files for bankruptcy. Automotive News Europe, June 22.

Bower, J.L., Christensen, C.M., 1995. Disruptive Technologies: Catching the Wave. Harvard Business Review, 43-53.

Breschi, S., Malerba, F., Orsenigo, L., 2000. Technological Regimes and Schumpeterian Patterns of Innovation. The Economic Journal 110, 388-410.

Brusoni, S., Prencipe, A., Pavitt, K., 2001. Knowledge Specialization, Organizational Coupling, and the Boundaries of the Firm: Why Do Firms Know More Than They Make? Administrative Science Quarterly 46, 597-621. 
California Energy Commission, 2012. Distributed Energy Resources Guide.

http://www.energy.ca.gov/distgen/ (Acc. 15 May, 2012)

Capstone, 2011. Capstone Turbine Corporation Annual Report 2011. , Chatsworth, CA.

Capstone Management, 2009. Ask Management. URL:

http://www.capstoneturbine.com/investor/ask-management.asp?page=32 (Acc. 19 October, 2012)

Cefis, E., Orsenigo, L., 2001. The persistence of innovative activities: A cross-countries and cross-sectors comparative analysis. Research Policy 30, 1139-1158.

Christensen, C., 2001. Making friends with disruptive technology: - an interview with Clayton

M. Christensen. Strategy \& Leadership 29, 10-15.

Christensen, C., Craig, T., Hart, S., 2001. The great disruption. Foreign Affairs, 80-95.

Christensen, C.M., 1997/2003. The Innovator's Dilemma. The Revolutionary Book that Will

Change the Way You Do Business. HarperCollins Publishers, New York.

Christensen, C.M., 2006. The Ongoing Process of Building a Theory of Disruption. Journal of Product Innovation Management 23, 39-55.

Christensen, C.M., Anthony, S.D., Roth, E.A., 2004. Seeing What's Next? Using the theories of innovation to predict industry change. Harvard Business School Press, Boston.

Christensen, C.M., Bower, J.L., 1996. Customer power, strategic investment, and the failure of leading firms. Strategic Management Journal 17, 197-218.

Christensen, C.M., Johnson, M.W., Rigby, D.K., 2002. Foundations for Growth. MIT Sloan Management Review 43, 22-31.

Christensen, C.M., Raynor, M.E., Anthony, S.D., 2003. Six Keys to Creating New-Growth

Businesses. Harvard Management Review, 3-6.

Christensen, C.M., Rosenbloom, R.S., 1995. Explaining the attacker's advantage:

Technological paradigms, organizational dynamics, and the value network. Research Policy 24, 233-257.

Cohen, S.S., Di Minin, A., Motoyama, Y., Palmberg, C., 2009. The Persistence of Home Bias for Important R\&D in Wireless Telecom and Automobiles. Review of Policy Research 26, 55-76.

Cohen, W.M., Levinthal, D.A., 1990. Absorptive Capacity: A New Perspective on Learning and Innovation. Administrative Science Quarterly 35, 128-152.

Colias, M., Rechtin, M., 2012. Sales up for EVs, hybrids. Automotive News April 23.

Cooper, A.C., Schendel, D., 1976. Strategic responses to technological threats. Business

Horizons 19, 61-69.

Dyerson, R., Pilkington, A., 2004. Expecting the unexpected: disruptive technological change processes and the electric vehicle. International Journal of Innovation and Technology Management 1, 165-183.

EPA, 2008. Technology characterization: Microturbines. Report prepared for the Environmental Protection Agency CHP Partnership program, Washington DC.

Foster, R.N., 1986. Innovation - The attacker's advantage. Macmillan, London.

Funk, J., 2009. The co-evolution of technology and methods of standard setting: the case of the mobile phone industry. Journal of Evolutionary Economics 19, 73-93.

Funk, J.L., 2010. Complexity, Critical Mass and Industry Formation: A Comparison of Selected Industries. Industry and Innovation 17, 511-530.

Gatignon, H., Tushman, M.L., Smith, W., Anderson, P., 2002. A Structural Approach to

Assessing Innovation: Construct Development of Innovation Locus, Type, and

Characteristics. Management Science 48, 1103-1122.

Geels, F.W., 2006. The hygienic transition from cesspools to sewer systems (1840-1930):

The dynamics of regime transformation. Research Policy 35, 1069-1082. 
Gerring, J., 2008. Case selection for case-study analysis: qualitative and quantitative techniques, in: Box-Steffensmeier, J. (Ed.), Oxford Handbook of Political Methodology. Oxford University Press, Oxford, pp. 645-684.

Gilbert, B.A., 2012. Creative destruction: Identifying its geographic origins. Research Policy 41, 734-742.

Gilfillan, S.C., 1935. Inventing the Ship. Follett Publishing Co, Chicago.

Govindarajan, V., Kopalle, P.K., 2006. Disruptiveness of innovations: measurement and an assessment of reliability and validity. Strategic Management Journal 27, 189-199.

Granstrand, O., Patel, P., Pavitt, K., 1997. Multi-Technology Corporations: Why They Have "Distributed" Rather Than "Distinctive Core" Competencies. California Management Review 39, 8-25.

Green Car Congress, 2011. Cumulative worldwide sales of Toyota hybrids top 3M units. URL: http:/www.greencarcongress.com/2011/03/cumulative-worldwide-sales-of-toyotahybrids-top-3m-units.html (Acc. 17 October, 2011)

Greene, N., Hammerschlag, R., 2000. Small and Clean Is Beautiful: Exploring the Emissions of Distributed Generation and Pollution Prevention Policies. The Electricity Journal 13, 5060.

Greimel, H., 2011. Nissan: Slow Leaf launch will speed up soon. Automotive News February 8.

Guilford, D., 2011. Watts up: A stampede of new electric cars. Automotive News March 7.

Hart, S.L., 2005. Innovation, Creative Destruction and Sustainability. Research-Technology Management 48, 21-27.

Helfat, C.E., Lieberman, M.B., 2002. The birth of capabilities: market entry and the importance of pre-history. Industrial and Corporate Change 11, 725-760.

Henderson, R.M., Clark, K.B., 1990. Architectural Innovation: The Reconfiguration of Existing Product Technologies and the Failure of Established Firms. Administrative Science Quarterly 35, 9-30.

Hobday, M., 1990. Semiconductors: Creative Destruction or US Industrial Decline? Futures 22, 571-585.

Hopkins, M.M., Martin, P.A., Nightingale, P., Kraft, A., Mahdi, S., 2007. The myth of the biotech revolution: An assessment of technological, clinical and organisational change.

Research Policy 36, 566-589.

Jacobides, M.G., Knudsen, T., Augier, M., 2006. Benefiting from innovation: Value creation, value appropriation and the role of industry architectures. Research Policy 35, 1200-1221. Karlberg, L.A., 2011. Sista chansen att beställa Tesla Roadster. Ny Teknik

Kash, D.E., Rycroft, R., 2002. Emerging patterns of complex technological innovation. Technological Forecasting and Social Change 69, 581-606.

King, A.A., Tucci, C.L., 2002. Incumbent Entry into New Market Niches: The Role of Experience and Managerial Choice in the Creation of Dynamic Capabilities. Management Science 48, 171-186.

Klepper, S., 1996. Entry, Exit, Growth, and Innovation over the Product Life Cycle. The American Economic Review 86, 562-583.

Leonard-Barton, D., 1992. Core Capabilities and Core Rigidities: A Paradox in Managing New Product Development. Strategic Management Journal 13, 111-125.

Macher, J.T., Richman, B.D., 2004. Organisational responses to discontinuous innovation: a case study approach. International Journal of Innovation Management 8, 87-114. Magnusson, T., 2003. Commercializing Cleaner New Technologies: The Case of Microturbine Generators. Technology Analysis \& Strategic Management 15, 349-361. 
Magnusson, T., Tell, F., Watson, J., 2005. From CoPS to mass production? Capabilities and innovation in power generation equipment manufacturing. Industrial and Corporate Change 14, 1-26.

Maine, E., Garnsey, E., 2006. Commercializing generic technology: The case of advanced materials ventures. Research Policy 35, 375-393.

Malerba, F., Orsenigo, L., 1996. Schumpeterian patterns of innovation are technologyspecific. Research Policy 25, 451-478.

McKinsey, 2012. Recharging China's electric vehicle aspirations. McKinsey \& Company, Beijing.

Murelio, A.C., 2000. New unit focuses on alternative-power and energy-management solutions like Ingersoll-Rand's new PowerWorks microturbine. URL:

http://www.electricnet.com/doc.mvc/From-PowerGen-2000-Ingersoll-Rand-launches-ne-0001 (Acc. October 19, 2012)

Murmann, P., Frenken, K., 2002. Towards a Systematic Framework for Research on Dominant Designs, Technological Innovations, and Industrial Change, Papers on Economics

\& Evolution. Max Planck Institute for Research into Economic Systems, Jena.

Nair, A., Ahlstrom, D., 2003. Delayed creative destruction and the coexistence of technologies. J. Eng. Technol. Manage. 20, 345-365.

O'Reilly, C.A.I., Tushman, M.L., 2004. The Ambidextrous Organization. Harvard Business Review 82, 74-81.

Orihashi, S., Heller, D.A., Higashi, H., 2010. Mitsubishi Motors Corporation: Leaving its deeps crisis for an electric future?, GERPISA, Berlin.

Pavitt, K., 1984. Sectoral patterns of technical change: Towards a taxonomy and a theory. Research Policy 13, 343-373.

Pavitt, K., 1986. 'Chips' and 'Trajectories': How Does the Semiconductor Influence the Sources and Directions of Technical Change?, in: MacLeod, R. (Ed.), Technology and the Human Prospect. Frances Pinter, London, pp. 31-54.

Raisch, S., Birkinshaw, J., 2008. Organizational Ambidexterity: Antecedents, Outcomes, and Moderators. Journal of Management 14, 375-409

Rechtin, M., 2012. Toyota touts hybrids on shopping network. Automotive News October 8.

Rechtin, M., Lindsay, C., 2012. New Fisker captain faces rough seas on Atlantic. Automotive News August 20.

Rosenberg, N., 1972. Factors affecting the diffusion of technology. Explorations in Economic History 10, 3-33.

Rosenbloom, R.S., Christensen, C.M., 1994. Technological Discontinuities, Organizational Capabilities, and Strategic Commitments. Industrial and Corporate Change 3, 655-685.

Roste, R., 2009. Transitions to sustainable innovation policy - the story of the Norwegian electric car Think, 1st European Conference on Sustainability Transitions, Amsterdam.

Rycroft, R.W., Kash, D.E., 2002. Path Dependence in the Innovation of Complex

Technologies. Technology Analysis \& Strategic Management 14, 21-35.

Schmidt, G.M., Druehl, C.T., 2008. When Is a Disruptive Innovation Disruptive?*. Journal of Product Innovation Management 25, 347-369.

Schumpeter, J.A., 1942/1994. Capitalism, Socialism \& Democracy, 5th ed. Routledge, New York.

Schumpeter, J.A., 1947. The Creative Response in Economic History. The Journal of Economic History 7, 149-159.

Seawright, J., Gerring, J., 2008. Case Selection Techniques in Case Study Research. Political Research Quarterly 61, 294-308.

Shnayerson, M., 1996. The Car that Could. The Inside Story of GM's Revolutionary Electric Vehicle. Random House, New York. 
Sierzchula, W., Bakker, S., Maat, K., van Wee, B., 2012. The competitive environment of electric vehicles: An analysis of prototype and production models. Environmental Innovation and Societal Transitions 2, 49-65.

Smith, D.J., 2002. Distributed Generation: Coming into Focus. Power Engineering, April 1. Sperling, D., Gordon, D., 2009. Two billion cars. Oxford University Press, Oxford.

Takeishi, A., 2002. Knowledge Partitioning in the Interfirm Division of Labor: The Case of Automotive Product Development. Organization Science 13, 321-338.

Tanner, C.D., n.a. Microtubines: a disruptive technology. URL http://www.retailenergy.com/articles/microturbines.htm (Acc. October 19, 2012)

Teece, D.J., 1986. Profiting from technological innovation: Implications for integration, collaboration, licensing and public policy. Research Policy 15, 285-305.

Tushman, M., Anderson, P., 1986. Technological Discontinuities and Organizational

Environments. Administrative Science Quarterly 31, 439-465.

Tushman, M.L., Smith, W.K., Wood, R.C., Westerman, G., O’Reilly, C., 2010.

Organizational designs and innovation streams. Industrial and Corporate Change 19, 1331-

1366.

USDOE, 2011. One Million Electric Vehicles by 2015. U.S. Department of Energy,

Washington DC.

USDOE, 2012. U.S. HEV Sales by Model. Alternative Fuels Data Center, URL

http://www.afdc.energy.gov/data/tab/fuels-infrastructure/data_set/10301 (Acc. May 1, 2012)

Utterback, J.M., Suarèz, F.F., 1993. Innovation, competition, and industry structure. Research Policy 22, 1-21.

Wahlman, A., 2012. 2012 Electric Car Sales Forecast. The Street, 6 July 2012. URL:

http://www.thestreet.com/story/11606766/1/2012-electric-car-sales-forecast.html (Acc. 3

October 2012)

Wang, H., Kimble, C., 2012. Business Model Innovation and the development of the electric vehicle industry in China, in: Calabrese, G. (Ed.), The Greening of the Automotive Industry. Palgrave/MacMillan, Basingstoke, pp. 140 - 153.

Webb, A., 2012. Shakeout hits small EV makers. Automotive News March 12.

Weiss, M., Patel, M.K., Junginger, M., Perujo, A., Bonnel, P., van Grootveld, G., 2012. On

the electrification of road transport - Learning rates and price forecasts for hybrid-electric and battery-electric vehicles. Energy Policy 48, 374-393.

Yao, M., Liu, H., Feng, X., 2011. The development of low-carbon vehicles in China. Energy Policy 39, 5457-5464. 